\title{
INTRODUCTION: RE-MAPPING ANGLO-JEWISH LITERARY HISTORY
}

\author{
By Cynthia Scheinberg
}

[I]t is not enough to make the Jew respected, but to have JUDAISM rightly reverenced; and to do this, there must be a JEWISH LITERATURE, or the Jewish people will not advance one step.

— Grace Aguilar, The Jewish Faith (1846)

THE ESSAYS COLLECTED in this issue of Victorian Literature and Culture seek to introduce Victorianists to some of the many Anglo-Jewish writers of nineteenth-century England. What differentiates this moment in Anglo-Jewish scholarship from most previous considerations is that we do not purport to fill a falsely constructed "void" of Anglo-Jewish literary silence; on the contrary, this collection seeks to amplify the fullness of nineteenth century Anglo-Jewish literary life. In 1846, Grace Aguilar, the important Anglo-Jewish writer and theologian, called out for the production of a "Jewish literature" that would aid the "right reverence[e] of Judaism," and "advance" the Jewish people in Victorian England. All too aware of the way exclusion from Hebrew literary and religious texts often precipitated assimilation, conversion, and more generalized alienation from Jewish religious life, Aguilar sought new tools to combat Jewish religious apathy. Detailing the subtle conversionary and theological assumptions that so-called secular — yet clearly Christian - literature often performed, Aguilar reasoned that a Jewish literature could provide Jewish readers - and especially Jewish women - with literary pleasure and a simultaneous sense of Jewish values and ethics; likewise, such a literature could recast the generally negative images of Jewish people and Judaism which pervade the long history of English literature. 1 With her emphasis on a Jewish literature, then, Aguilar sought to claim the cultural and ideological power literature held in Victorian England for specifically Jewish uses. Significantly, Aguilar's tone in the statement above suggests that she saw no such Jewish literature in past moments of Anglo-Jewish history; Aguilar's intensive production of such a literature in a variety of genres was her own response to this desire for Jewish literature. ${ }^{2}$

The reconstruction of a Victorian Anglo-Jewish literature has not been a case of simply retrieving lost texts; it has also entailed a re-mapping of some central assumptions 
about the English literary tradition and attendant notions of value and canon that have contributed to the almost total disregard of the writers considered here. It is worth noting that it is not only Christian literary scholarship that has overlooked the work of nineteenthcentury Anglo-Jewish writers. Examining a series of moments in Anglo-Jewish literary history in roughly fifty year increments, it seems that each generation of Jewish critics who take up the question of Anglo-Jewish literature depend upon the assumption that there was no viable nineteenth-century tradition of Anglo-Jewish literature in order to generate his or her theory of the "future" of Anglo-Jewish literature. ${ }^{3}$ Thus, fifty-eight years after Aguilar's call for a Jewish literature in English, Lucien Wolf, the influential and prolific president of "The Union of Jewish Literary Societies," addressed the topic of "Anglo-Jewish Literary Ability"; after a sympathetic recollection of some of the work of nineteenth century writers, including Aguilar, he concludes his 1904 address by naming their legacy "a dismal record of literary failures" and suggests that the previous failure of a coherent "Anglo-Jewish literary society" was on account of "the extraordinary intellectual apathy in the community" (6). Framing his speech with a traditional Jewish blessing — the Shehechianu, which offers thanks for having arrived safely at a particular momentous occasion - Wolf suggests that the continued presence of a "Union of Jewish Literary Societies" is somewhat of a miracle; he concludes his speech by stating: "It is only today that we are beginning to garner the full fruits in the spontaneous and widely ramifying intellectual interests of our youth, and in the earnestness and tenacity with which our best minds now participate in our work" (12). In his emphasis on his contemporary moment — "only today" - and his praise for the work of "our youth," Wolf perpetuates the sense of a past void in Anglo-Jewish literature; this representation of a "failed" and "apathetic" literary ancestry allows Wolf to construct his/her own moment as the one in which the true genius of Anglo-Jewish literature will be revealed.

Almost fifty years after Wolf, a remarkably similar evaluation of Anglo-Jewish literary life occurred in the pages of the journal Commentary. At the start of his 1949 article "What Can We Do About Fagin?" a young Leslie Fiedler wrote:

\footnotetext{
Made sensitive by Hitler and the collapse of the univeralist dream, we re-examine our literary heritage as Jewish writers and readers of English — and we wince! Looking again at Lawrence or Pound, Shakespeare, Chaucer, Marlowe, Pope, Wordsworth, Scott or Dickens, T. S. Eliot, Charles Williams or Graham Greene, everywhere we come upon a myth of the Jew, central to our whole culture, before which as Jews we are embarrassed, dumb. (412)
}

From Fiedler's viewpoint, the Jewish response to a literary tradition of English anti-Semitism and anti-Judaism can be characterized as an "embarrassed" silence; at the end of the essay, he writes, "we can begin to build the rival myths of our meaning for the Western world, other images of the Jew to dispossess the ancient images of terror" and goes on to list those who have begun such work: Kafka, Proust, Joyce, and Bellow. For Fiedler, Jewish literature in English began to take its first steps in the twentieth century, and with the help of non-Jewish writers as well as Jewish ones; he and his contemporaries, it seems, remained ignorant of a nineteenth-century Anglo-Jewish literary tradition. Indeed, Fiedler's essay generated a "symposium" in the two following issues of Commentary; in this forum, twenty of the most prominent Jewish English and American critics and authors of the day were asked to comment on "The Jewish Writer and the English Literary Tradition," and not one 
of these writers mentioned any Anglo-Jewish writers in the nineteenth century. With a perfunctory mention of Kafka, this generation of critics assumed that the questions surrounding Anglo-Jewish literary identity were best examined through the work of Christian writers - Shakespeare, Scott, Dickens, Joyce and T. S. Eliot - and that the building of a body of autonomous "Jewish literature" would thus "begin" in the post-Holocaust Jewish generation. 4

This collection of essays in Victorian Literature and Culture - coming fifty years after Fiedler's pronouncements - offers a distinct challenge to those who would construct nineteenth-century Anglo-Jewish literary tradition as "dumb." The essays in this volume recognize the multiplicity and diversity of the nineteenth century Anglo-Jewish literary tradition; read collectively, these essays illuminate the variety of specifically Jewish answers to what has been the awkwardly conceived (Christian) rhetoric of "the Jewish problem." The research and criticism represented in this volume reminds us that the Jews in Victorian England were not only the productions of Christian imagination; on the contrary, the growing stability of a Jewish community in nineteenth century England produced a number of writers whose work has important theoretical ramifications for both Jewish studies and Victorian studies today. Indeed, the original scholarship on Anglo-Jewish authors represented in this volume - like the groundbreaking scholarship on gender and race in recent years - positions the once silenced and objectified Jewish "others" of English literary history as the speaking subjects of scholarly inquiry. And while it is not clear that Grace Aguilar would deem the all texts examined here as promoting "the right reverence of Judaism," putting her work in context with later Anglo-Jewish authors lets Victorianists chart the highly unstable category of "Jewish identity" as it emerged from the experiences and pens of Anglo-Jewish writers in nineteenth century England.5

Since these essays present groundbreaking research on writers and texts that have been mostly ignored for over a century, the notion of an Anglo-Jewish literary tradition may come as a surprise to many Victorianists. However, it is worth noting that this collection barely scratches the surface of Anglo-Jewish literary output of the Victorian era; while not exhaustive, the six essays represented raise some of the most significant issues that concerned nineteenth-century Anglo-Jewry, issues about racial, religious, gendered and class identity that likewise mark the newest research in more generalized Victorian studies as well. Recent scholarship on primarily Christian writers has made it abundantly clear that in Victorian England, the topic of Jewishness was of paramount importance in the Christian press and scholarship; scholars in history, literature, and religious studies have noted the outpouring of texts and political debates that surrounded the historical emergence of a Jewish community in the mid-nineteenth century in England, and there have been numerous studies charting the complex narrative of Jewish political enfranchisement that accompanied the growth in the Victorian Anglo-Jewish community. ${ }^{6}$

The expulsion of the Jews from England in 1290 and their gradual reentry in the seventeenth century meant that there was no actual Jewish community in over four hundred years of England's history. That historical narrative reminds us that Jewishness in England was experienced quite differently — and had a very different history of representation - than other European Jewries with a more consistent ghetto population. This specific narrative of Anglo-Jewish exile and resettlement is crucially important to consider when re-constructing Anglo-Jewish literary history, and when thinking about the particular meaning of Jewish difference in and against the many racial and cultural others with 
whom England interacted throughout its colonizing regime. Unlike the colonized racial other who existed "off" England's literal landscape, the rise of the Jewish community from the seventeenth to nineteenth centuries brought English culture in direct contact with an other who challenged English assumptions of race, culture and ethnicity. Even further, Jews since the first centuries of Christianity were always already constructed as the paradigmatic religious other as constructed through the immense and mythic power of the Christian Bible.

The emergence of the increasingly economic and politically successful Jewish community in nineteenth century England was thus an historical phenomenon which became of paramount concern — both in theory and in reality - to the gatekeepers of Victorian (Anglican) culture. Jewish difference was a site where a number of historical and ideological discourses converged; the figure of the Jew was constantly invoked at this moment when Christian authority was under heightened scrutiny in the era of religious skepticism due to Darwinism, when the German "Higher Criticism" initiated the academic questioning of the status of Biblical Jewish history, when concepts of racial difference began to be codified in patterns that tended to support the notion of Anglo-Saxon superiority, and when the political enfranchisement of non-Anglicans - Jews, Catholics and Dissenters became of paramount importance in Parliamentary debates. By the mid part of the century, "the Jewish question" was to Christian England not only a question of what to do with a growing minority culture; it became a question that challenged the very definition of English (and specifically Anglican) national identity.

The essays collected here suggest that there was no one Jewish "answer" to the challenges and queries raised by the major Christian clerics and critics in Victorian England; on the contrary, what we learn from the essays that follow is that there were many different Jewish constructions of Jewishness in Victorian England, constructions that changed depending on the varied approaches to historical location, gender, class, and religion that mark the diversity of Anglo-Jewish Victorian subjects and experience. The essays have been ordered chronologically, and reading them in this order offers some important insights about Anglo-Jewish cultural and literary identity, and about the changing historical circumstances of the Jewish community - or rather communities - in Victorian England.

One of the most important questions raised by a newly thriving Jewish community in England was: under what rubric of nationalism could Jews be classified in imperialist England, and to what national identity did Jews owe allegiance in the pre-Zionist period? Judith Page's essay on Judith Montefiore's Private Journal, an account of her 1827 pilgrimage to Jerusalem with her husband Moses Montefiore, offers an important starting place for these essays. Page's analysis of this travel journal suggests the broad range of genres that characterize the Victorian Anglo-Jewish literary effort; Montefiore's "private" text offers a sense of the profound seriousness that marked first generation Sephardic Jewish families' sense of spiritual and communal leadership for Anglo-Jewry — and indeed world Jewry. As Page demonstrates, Montefiore translates her literal and often difficult physical journey into a spiritual journey; while sharing many qualities with those of Christian woman travelers to the "Holy Land," Montefiore offers a "distinctly Jewish perspective" and approach to the meaning of this particular journey in her own and Anglo-Jewish communal experience; this perspective challenges and recasts the travel writing of Christian women and provides a very different set of (Jewish) responses to the geographical and historical significance of Biblical topography. 
Montefiore thus offers us an important example of pre-emancipation Anglo-Jewish women's identity; when we read her "private text" in context with Grace Aguilar's (1816-47) very public work a decade later, we can observe a similar emphasis on Jewish spirituality. ${ }^{7}$ Yet Aguilar's early move into a quite public publishing career insists on her careful negotiation of the dual assumptions of a heterogeneous audience of Christians and Jews, a complexity with which Montefiore did not need to be concerned in her unpublished, private journal. Daniel Harris's essay on Grace Aguilar's poetry and non-fiction prose situates Aguilar in and against the complexities of her very public identity as a single and outspoken Jewish woman writer in a culture which still challenged the authority of Christian women writers, let alone those who remained fully identified with Jewish culture and religion. Harris focuses on Aguilar's interest in patterns of and identifications with historical Jewish displacement, and he highlights Aguilar's own complex discourse on the nature of pre-Zionist Anglo-Jewish national identity. Charting her identification with the figure of the "wandering" Hagar, Harris concludes his essay with an analysis of the ways Aguilar's poetic discourse of displacement intersects with the very real political concerns of Anglo-Jews before the enfranchisement of 1857.8

These opening two essays on Montefiore and Aguilar thus help chart the specific concerns of two observant Jewish women in the earlier part of the century. Both Aguilar and Montefiore, as part of an earlier Sephardic community, see the need for a specific kind of spiritual leadership that might bolster a positive sense of Anglo-Jewish religious and cultural identity. The four other writers explored in this collection might best be understood as the second generation of the Victorian Anglo-Jewish literary tradition as it emerges in the 1880's; these essays are grouped to highlight the very different responses and concerns that mark Anglo-Jewish writing of the latter part of the nineteenth century. There were of course a number of important Jewish writers working in the forty years between Aguilar's death in 1847 and Amy Levy's first volume of poems in 1881; Emma Lyons, Marion Hartog (nee Moss), Ann Maria Goldsmid, Philip Abraham and of course Benjamin Disraeli, to name only a few, contributed widely to the body of Anglo-Jewish literary life. ${ }^{9}$ As well, this mid Victorian period saw a number of events that would prove momentous in Anglo-Jewish history and which had great influence on the writers of the later part of the century. Without offering a full historical narrative here, mention of a few key trends and moments helps contextualize the changes in Anglo-Jewish thinking that are so evident when we juxtapose Montefiore and Aguilar's work against that of Amy Levy, Julia Frankau, Benjamin Farjeon, and Israel Zangwill in the latter part of the century.

In 1840, Moses Montefiore helped to orchestrate the exoneration of the Jews of Damascus from a charge of blood libel. This event marked an important moment in which Jewish political influence was fully evident in international diplomacy; significantly, after this event, having just witnessed all too vividly scenes of extreme anti-Semitic persecution in Damascus, Montefiore made a second trip to Palestine and sought to establish agricultural settlements for Jews in Palestine. Some have argued this was the first proto-Zionist organization. With the discourse of a possible Jewish return to the Holy Land which continued with increasing force until the end of the century, we can chart a gradual shift in the construction of a specific Diaspora identity that marks so much Jewish writing in England and Europe in the earlier nineteenth century writers.

In 1858, Baron Lionel de Rothschild took his seat in Parliament, the first Jew to take a revised oath of government office on a Hebrew Bible, an oath which omitted for the first 
time the phrase Rothschild had been elected to this office several times before ever being able to serve, and his battle to legally omit the phrase "on the true faith of a Christian" in his oath created perhaps the single most important public debate on the meaning of Jewish in English history. ${ }^{10}$ Benjamin Disraeli had of course been an elected member for some time, but his baptism in childhood made him eligible for English politics long before unconverted Jews could serve in national government. Despite his conversion, however, Disraeli's influence on the construction of Anglo-Jewish identity cannot be overlooked; though technically an Anglican, Jewish and Christian Victorian culture understood him to be, in some essential way, Jewish, as the overtly anti-Semitic political cartoons of the day clearly illustrate. ${ }^{11}$ Likewise, Disraeli's own theories of Jewish identity in his quite successful novels often celebrated some kind of essentialized and universalized Jewish essence to which Disraeli maintained allegiance despite a quite public representation of his Christian self. 12

Yet perhaps the single most important historical event that marked the later years of Victorian Anglo-Jewry was the huge influx of Eastern European Jews escaping the widespread pogroms and other persecutions in the latter part of the century. Where earlier Anglo-Jewish middle class identity had developed first out of specifically Sephardic (Spanish and Portuguese) as well as German roots, this newer Eastern European Ashkenazi community was extremely poor and likewise brought with it a very different set of Jewish traditions, communal identity and culture. The wealthier and more established AngloJewish communities of the day looked on this group of "brethren" with a mixture of charity and distance; while clearly in need of help, these new Jews threatened the "bargain" - as Michael Galchinsky has termed it — earlier Anglo-Jewry seemed to strike with Victorian culture, namely to assimilate publicly and maintain Jewish identity in private. Yet suddenly, there was a vast new public face for Anglo-Jewishness, one that was very publicly visible to the rest of English culture as a different kind of "Jewish problem," generally and often falsely associated, as with most newly immigrated groups, with crime and poverty. Many of these immigrants maintained stricter ties to religious orthodoxy and tight-knit communities; thus the religious identity that earlier generations of Anglo-Jewry had often relegated to private life was - in the lives of the less assimilated Eastern European Jews - another marker of their difference from the established Anglo-Jewish communities and larger Victorian society.

This wave of Ashkenazic, Eastern European immigration created a fascinating new intersection between the narratives of Jewish history in England and Europe. Not surprisingly, then, given the very new concerns of Anglo-Jewry, Jewish writers take up a new set of questions and concerns which often seem far removed from Montefiore and Aguilar's earlier work. Linda Hunt Beckman's essay on Amy Levy (1861-1889) explores how Levy's public and private writing responds to the "historical shifts in attitude" which mark the latter half of Victorian Anglo-Jewish concerns. Levy's work, and especially her poetry, has received a welcome revival since the publication of Melvyn New's partial collection of her writing in 1993, and Hunt Beckman's essay builds on the information we have on Levy by drawing on unpublished manuscripts and biographical materials in order to offer new insights on Levy's attitudes on Jewishness. Hunt Beckman (and others in this collection) take up Sander Gilman's influential work on "Jewish self-hatred" which has punctuated so much critical work on Jewish writers in the latter part of the nineteenth century. 13 Countering recent criticism which has read Levy's fiction as evidence of her own negative 
associations with a Jewish identity, Hunt Beckman argues that Levy herself interrogated the very idea of self-hatred in many of her own works, and that close attention to Levy's public and private writings reveals a changing narrative of attitudes toward Jews and Judaism that can be traced through her short career.

The question of Jewish self-hatred is also a theme in Michael Galchinsky's essay on Julia Frankau's novels. Galchinsky locates Frankau at the end of a trajectory of Jewish writers who all confronted the emerging Victorian (Christian) discourses on the "science" of race which, in the nineteenth century, constructed Jewish identity in specifically racial terms. Reading Frankau against Jewish writers who sought to reject these pseudoscientific theories of Jewish racial difference and inferiority, Galchinsky suggests that Frankau's adoption of a theory of Jewish racial inferiority distinguishes her fiction in ways that are often hard for contemporary readers to applaud. Given Frankau's troubling racial politics, Galchinsky frames his readings by asking crucial methodological questions about the politics of "recovering" lost writers who propound theories of Jewishness that we might prefer to leave "lost"; thus, this essay is important for both the new readings of Frankau it offers as well as for its larger theoretical concerns about the current re-construction of Anglo-Jewish literary history with which this collection of essays participates.

Many of these themes raised in Galchinsky's article are taken up in Michelle Persell's essay on the few novels of Jewish content written by the prolific Benjamin Farjeon (18381903). Persell argues that Farjeon's attitudes toward Jewishness are best understood when read through an economic discourse; for Farjeon, Persell argues, Jewish identity can be described as "a set of values and behaviors consistent with capitalist activity" which position the Jew as an important partner in the "economics of empire building" which mark larger bourgeois Victorian society. Persell's reading of Farjeon offers a glimpse of the ways Jewish writers sought to depict the Jew as a full participant in English nation building, and Persell's conclusions are particularly interesting when read with and against mythic negative stereotypes of Jewish avarice, as well as with and against theories of Jewish nationalism that re-emerge with the growing interest in the establishment of a Zionist state.

The collection of essays on Anglo-Jewish Victorian authors ends with Meri-Jane Rochelson's essay on the fiction of Israel Zangwill, and it is fitting to end with the figure who for many was the Jewish writer of later nineteenth-century England and America. Indeed, most well known for his 1892 novel Children of the Ghetto and for coining the term "The Melting Pot" in his 1908 play of that title, Zangwill came to be hailed as a writer who, in Rochelson's words, "revealed and explained an alien community to its non-Jewish neighbors and made the universe of Jewish immigrants more intelligible to their acculturated coreligionists." Rochelson charts Zangwill's construction of the relationships between modern culture, Christianity, and traditional Judaism; in Zangwill's work, juxtaposition of "old" and "new" Jewish identity is highlighted repeatedly. Whereas the essays that precede this one suggest that Zangwill's contemporaries had long abandoned the religious dimension of Jewish identity that was so central to earlier writers like Aguilar and Montefiore, Zangwill's stories seek to represent — often with a mix of nostalgia and alienation — the more traditional world of Eastern European orthodoxy. Rochelson suggests that Zangwill's fiction recasts the outright rejection of that ghetto world that marked so much Jewish and Christian writing of the day, and Rochelson's recognition of his respect for a tradition and culture lost to most "modern" Jews recasts the polarization of culture and religion which has almost become a stereotype in nineteenth-century Jewish studies. 
Nadia Valman's review essay examining the recent critical work on Anglo-Jewish literature concludes this entire collection. Valman offers a more detailed analysis of the roots of Anglo-Jewish literary history to which I have only alluded in this introduction, and then goes on to review some of the newest work in Anglo-Jewish literary studies in relation to "both contemporary critical theory and Jewish historiography." Her review essay thus provides a larger theoretical and historical context in which to read the essays represented here, as well as charting the larger theoretical and methodological issues that will generate future work in Anglo-Jewish studies.

As editor of this collection of new essays on Anglo-Jewish literary history, I feel a certain kinship with Aguilar, Wolf, and Fiedler in marking this historical moment as an important one for the future of Anglo-Jewish literary life. Indeed, I am tempted to offer my own Shehechianu for what may be the first collection of specifically literary essays to represent some of the richness of nineteenth century Anglo-Jewish literary life. While there may be a certain comfort in representing one's own generation as the one in which Jewish studies were created, it is time to recognize that despite a critically important new scholarly interest in the last ten years, the fields of Jewish studies, Jewish literature in English and even Jewish women's studies were not born in the twentieth century. What of course remains to be done is the serious work of re-publication, so that future scholars and students can build on our understanding of Anglo-Jewish literary life, and we can begin to interrogate a British literary canonical politics which has virtually erased these nineteenthcentury Jewish writers until quite recently. Our hope is that with this collection of essays, we can now begin the process of grafting the work of twentieth-century Jewish studies back onto its nineteenth-century roots. Starting with this collection, we discover that Victorian Anglo-Jews had many varied "answers" to the "questions" posed to their identity by not only Christian culture, but also by the different Jewish cultures in which they themselves were also situated. With the recognition of a rich and diverse Anglo-Jewish literary life, we have new tools through which to complicate our theories of how Jewish identity inflected Victorian culture — not just in the form of an abstracted, ahistorical, and mythologized "Hebraism," but rather in the specific voices of real Jewish writers whom we hope will have long lives in English literary history.

\section{Mills College}

\section{NOTES}

1. Aguilar raises this discussion of the importance of a specifically Jewish literature, as well as her critique of the supposed "universality" of Christian texts in The Jewish Faith (1846) and the conclusion to The Women of Israel (1845).

2. It is important to note that there were eighteenth century Anglo-Jewish writers as well, though most recent scholarship focuses on the nineteenth century. For a survey of both Jewish writers and Christian writers concerned with things Jewish, see especially Modder. Clearly, the literary life of Anglo-Jews prior to the Victorian era is a topic ripe for scholarly attention. See Calisch.

3. An interesting exception to this erasure of a nineteenth century Anglo-Jewish literary tradition comes from critics who explicitly consider women writers, critics like Abrahams, Spielman, Galchinsky. I would contend that one of the reasons for the critical erasure of the Anglo-Jewish literary tradition by androcentric scholars like Fiedler (below) is that they 
rarely consider women writers at all; because Jewish women occupied so much space in the Anglo-Jewish literary scene, ignoring them has in part entailed ignoring an entire literary tradition. For more on the reasons why Jewish women writers were so prominent in Victorian England, see Galchinsky.

4. Likewise, the excellent more recent studies of Jewishness and "the Jewish Question" by Ragussis, Cheyette also remain primarily concerned with Christian writers' understanding of Jewish identity. Ragussis's chapter on Grace Aguilar remains an exception to this general trend. See also note 7.

5. It is important to note that English and American Jewish writers often enjoyed transatlantic success; for example Aguilar's first book was published by the American Rabbi Isaac Leeser. Current research is beginning to uncover the correspondence between English and American Jewish writers in this period.

6. See especially Salbstein, Jacob Katz, and Feldman for studies of the political emancipation of the Jews. See David Katz and Endelman for studies of historical context prior to emancipation.

7. "Pre-emancipation" refers to the historical period before Jews had the full political rights in England. See below.

8. In addition, Harris's essay offers extensive footnotes and information on larger issues in Anglo-Jewish culture and politics as well as current trends in Jewish studies.

9. See forthcoming work on gender and Judaism by Valman; see also Cheyette and Ragussis on Disraeli's approach to Jewish identity, Anglo-Jewish political emancipation, and Jewish literary representation.

10. See note 6 for important references in this debate. See also Thomas Babington Macaulay's famous speech to Parliament on Jewish civil emancipation, "Civil Disabilities of the Jews" in the Edinburgh Review (January, 1831).

11. See Ragussis for a fascinating collection of those cartoons.

12. See especially, Alroy (1833), Coningsby (1844), Sybil (1845), and Tancred (1847). Ragussis offers an important contextualization of these novels in larger issues of Jewish identity.

13. See Gilman's Introduction for his theory of Jewish self-hatred.

\section{WORKS CITED}

Abrahams, Beth-Zion Lask. "Grace Aguilar: A Centenary Tribute." Jewish Historical Society of England Transactions 16 (1945-51), 137-58.

Aguilar, Grace. The Spirit of Judaism (and collected poems). Philadelphia: No. 1 Monroe Place, 1842.

. Women of Israel. NY: D. Appleton, 1901 (1845).

The Jewish Faith. Philadelphia: 1884 (1846).

Calisch, Edward. The Jew in English Literature, as Author and Subject. First published 1909. Reprinted: Port Washington, NY: Kennikat P, 1969.

Cheyette, Bryan. Constructions of the Jew in English Literature: Cambridge: Cambridge UP, 1993.

Endelman, Todd M. Radical Assimilation in English Jewish History 1656-1945. Bloomington: Indiana UP, 1990.

Feldman, David. Englishmen and Jews: Social Relations and Political Culture. New Haven: Yale UP, 1994.

Fiedler, Leslie A. "What Can We Do About Fagin?” Commentary 7.5 (May 1949). 411-18. (See also follow-up articles in subsequent edition of Commentary by various authors: "Symposium: The Jewish Writer and the English Literary Tradition.” Commentary 8.3-4 (Sept.-Oct., 1949).

Finestein, Israel. Jewish Society in Victorian England. London: Vallentine Mitchell, 1993. 
Frankel, William. Friday Nights: A Jewish Chronicle Anthology. London: Jewish Chronicle Publications, 1973.

Galchinsky, Michael. The Origin of the Modern Jewish Writer: Romance and Reform in Victorian England. Detroit: Wayne State UP, 1996.

Gilman, Sander. Jewish Self Hatred. Baltimore: Johns Hopkins UP, 1986.

Katz, David. The Jews in the History of England, 1485-1850. Oxford: Oxford UP, 1994.

Katz, Jacob. Jewish Emancipation and Self Emancipation. Philadelphia: The Jewish Publication Society, 1986.

Lipman, V. D. Social History of the Jews in England, 1850-1950. London: Watts, 1954.

Modder, Montagu Frank. The Jew in the Literature of England. Philadelphia: The Jewish Publication Society, 1939.

New, Melvyn. The Complete Novels and Selected Writings of Amy Levy. Orlando: UP of Florida, 1993.

Ragussis, Michael. Figures of Conversion: "The Jewish Question \& English National Identity." Durham, NC: Duke UP, 1995.

Salbstein, M. C. N. The Emancipation Of the Jews in Britain: The Question of Admission of the Jews to Parliament, 1828-1860. Rutherford: Associated University Presses, 1982.

Spielman, Mrs. Meyer A. "Jewish Woman Writers." Presidential Address to the Union of Jewish Literary Societies. November 10, 1913.

Valman, Nadia. "Gender and Judaism in Victorian Culture." Unpublished manuscript (in progress).

Wolf, Lucien. "Anglo-Jewish Literary Ability." Presidential Address to the Union of Jewish Literary Societies. September 26, 1904. 